\title{
A trapped Philippine Sea plate origin for MORB from the inner slope of the Izu-Bonin trench
}

\author{
Susan M. DeBari ${ }^{\mathrm{a}, *}$, Brian Taylor $^{\mathrm{b}}$, Khalil Spencer ${ }^{\mathrm{b}}$, Kantaro Fujioka ${ }^{\mathrm{c}}$ \\ a Geology Department, Western Washington University, Bellingham, WA 98225, USA \\ b Department of Geology and Geophysics, University of Hawaii, Honolulu, HI 96822, USA \\ c Japan Marine Science and Technology Center, Yokosuka, Japan
}

Received 30 December 1998; accepted 13 October 1999

\begin{abstract}
Basement outcrops sampled by submersible and dredge from the inner slope of the Izu-Bonin trench at $32^{\circ} \mathrm{N}$ and 6200-6700 m water depth have a distinct mid-ocean ridge basalt (MORB) chemistry unlike any other rocks previously sampled in the Izu-Bonin arc. They are low $\mathrm{K}$ tholeiites with moderate $\mathrm{TiO}_{2}(0.7-1.8 \mathrm{wt} \%)$, extremely low $\mathrm{Ba}(1.5-7$ parts per million), low $\mathrm{Ba} / \mathrm{La}(1.2-3)$ and are depleted in light rare-earth elements. These samples could represent either an accreted piece of subducting Pacific plate or a trapped remnant of Philippine Sea plate on which the Izu-Bonin arc was built. Although their major and trace element chemistry do not help to distinguish their source, the $\mathrm{Sr}, \mathrm{Nd}$ and $\mathrm{Pb}$ isotopes clearly support a Philippine Sea plate origin. The isotopic signature of the inner trench slope samples matches that of Philippine Sea plate lavas, with ${ }^{87} \mathrm{Sr} /{ }^{86} \mathrm{Sr}=0.70321-0.70373,{ }^{143} \mathrm{Nd} /{ }^{144} \mathrm{Nd}=0.513057-0.513077$ and ${ }^{206} \mathrm{~Pb} /{ }^{204} \mathrm{~Pb}=18.2-18.5$. The samples have elevated ${ }^{207} \mathrm{~Pb} / 204 \mathrm{~Pb}(15.3-15.5)$ and ${ }^{208} \mathrm{~Pb} /{ }^{204} \mathrm{~Pb}(38.0-38.2)$ values compared to the Northern Hemisphere reference line (NHRL) and their isotopic signature is distinct from the Mesozoic Pacific MORB being subducted. These are the first samples of trapped Philippine Sea oceanic crust discovered in the IzuBonin-Mariana arc. They require that models for the formation of intra-oceanic arc crust account for pre-existing oceanic crust and that estimates of arc magma production rates are lowered accordingly. (C) 1999 Elsevier Science B.V. All rights reserved.
\end{abstract}

Keywords: Izu-Bonin Arc; mid-ocean ridge basalts; magmatism; basement

\section{Introduction}

Three dives to between 6100 and $6500 \mathrm{~m}$ water depth were made on the inner trench slope of the Izu-Bonin arc at $31^{\circ} 59^{\prime} \mathrm{N}$ (Fig. 1) using the manned Japanese submersible, Shinkai 6500.

\footnotetext{
* Corresponding author. Tel.: +1 360-650-3000;

Fax: +1 360-650-7302; E-mail: debari@cc.wwu.edu
}

The primary goal was to recover arc basement from the trench slope. Seismic reflection profiles $[1,2]$ show that the steep inner slope of the IzuBonin trench likely exposes arc basement below $5 \mathrm{~km}$ water depth, above and possibly below a terrace of serpentinite seamounts (Fig. 1). This is corroborated by two SeaMARC II sidescan swaths near $32^{\circ} \mathrm{N}$ (Fig. 2) that reveal high amplitude acoustic backscatter from the slope between 5200 and $6700 \mathrm{~m}$. Together with the seismic reflection profiles, the sidescan data indicate that 
basement rocks are at, or within a few meters of, the surface. Surprisingly, the central Izu-Bonin inner trench slopes were virtually unsampled prior to our dives, though the potential existed at $32^{\circ} \mathrm{N}$ to sample a basement section up to $1500 \mathrm{~m}$ thick.

The rationale for these dives was to exploit the extremely rare opportunity to study in situ the basement of an intra-oceanic island arc. Our aim was to make a composite stratigraphic and structural profile of the basement section above $6500 \mathrm{~m}$ water depth and to sample the deepest and most seaward section of the central IzuBonin arc basement reachable by submersible (only 35-45 km from the trench axis) (Fig. 1). Ocean Drilling Program (ODP) Site 786, on the outer arc high just upslope from our dive sites, sampled boninitic and tholeiitic volcanic rocks similar to those exposed subaerially on the Bonin Islands. Diving on the trench slope $\sim 40 \mathrm{~km}$ east and $3000 \mathrm{~m}$ lower than ODP Site 786 could sample the plutonic roots to these volcanic systems (Fig. 1).

An additional goal of these dives was to test alternate models of forearc evolution and inner trench slope tectonism. It has been thought that only very minor, and probably ephemeral, tectonic accretion occurs (along the very base of the slope) at the Izu-Bonin-Mariana and TongaKermadec trenches. In the Mariana trench, arc lavas drilled at great depths on the inner trench slope were explained as the result of extreme subsidence resulting from tectonic erosion of the forearc by high-angle normal faulting [3]. In contrast, in the Tonga trench, an apparently coherent crustal and upper mantle section on the inner slope was interpreted to reflect flexural uplift of the arc footwall beneath a low angle normal fault [4].

Our dives produced surprising results. Instead of finding arc-related volcanic rocks or plutonic basement rocks that would support either of the two forearc evolutionary models proposed above, we recovered N-MORB-type diabase and basalt. These findings presented two likely possibilities, that the forearc includes remnant Philippine Sea plate crust or that Pacific plate crust has been accreted. In either case, the forearc clearly does not consist solely of arc-related rocks. The forearc may comprise trapped segments of Philippine Sea plate MORB that are interspersed among younger, arc-related boninitic and tholeiitic volcanic rocks or the forearc may have grown by episodic, previously unrecorded accretion events from the Pacific plate [5]. The isotopic results that we present in this paper strongly support the former.

\section{Geologic setting and tectonic history of the Izu-Bonin arc}

The Izu-Bonin arc, south of the island of Honshu in the Japan archipelago (Fig. 1), is one of the best-surveyed intra-oceanic volcanic arcs as a result of studies by Japanese, American and international (i.e. ODP) agencies. The trench is well developed and extends to nearly $10 \mathrm{~km}$ water depth. The $200 \mathrm{~km}$ wide forearc region includes an inner trench slope with a basal terrace formed by sediments ponded behind and between serpentinite seamounts, an outer arc high that becomes subaerial in the Bonin Islands and a thick forearc sedimentary basin east of the active arc volcanoes. The backarc region includes active rift basins as well as cross-chains of submarine arc volcanoes that extend into the Shikoku Basin.

The history of the Izu-Bonin arc system has been described in detail by B. Taylor [6]. The earliest arc volcanism occurred during the middle and late Eocene, when a vast terrane of boninites and island arc tholeiites ( $>300 \mathrm{~km}$ wide) was formed. Development of a modern-style volcanic arc began by the early Oligocene, accompanied by intense tholeiitic and calcalkaline volcanism that continued until $27 \mathrm{Ma}$. The Eocene-Oligocene arc massif was stretched during protracted Oligocene rifting. Arc volcanism decreased in intensity at $27 \mathrm{Ma}$ and was at a minimum from 23 to $17 \mathrm{Ma}$, with no record of volcanic ash from 23 to $20 \mathrm{Ma}$. This minimum corresponds to early spreading of the Shikoku backarc basin (24-15 Ma). Middle Miocene to Holocene Izu-Bonin volcanism developed a volcanic front oriented $3^{\circ}$ counter-clockwise from the Oligocene frontal arc and has increased in intensity to a Pliocene-Quaternary maximum. Neogene magmatism along the volcanic front has been focused on bimodally 


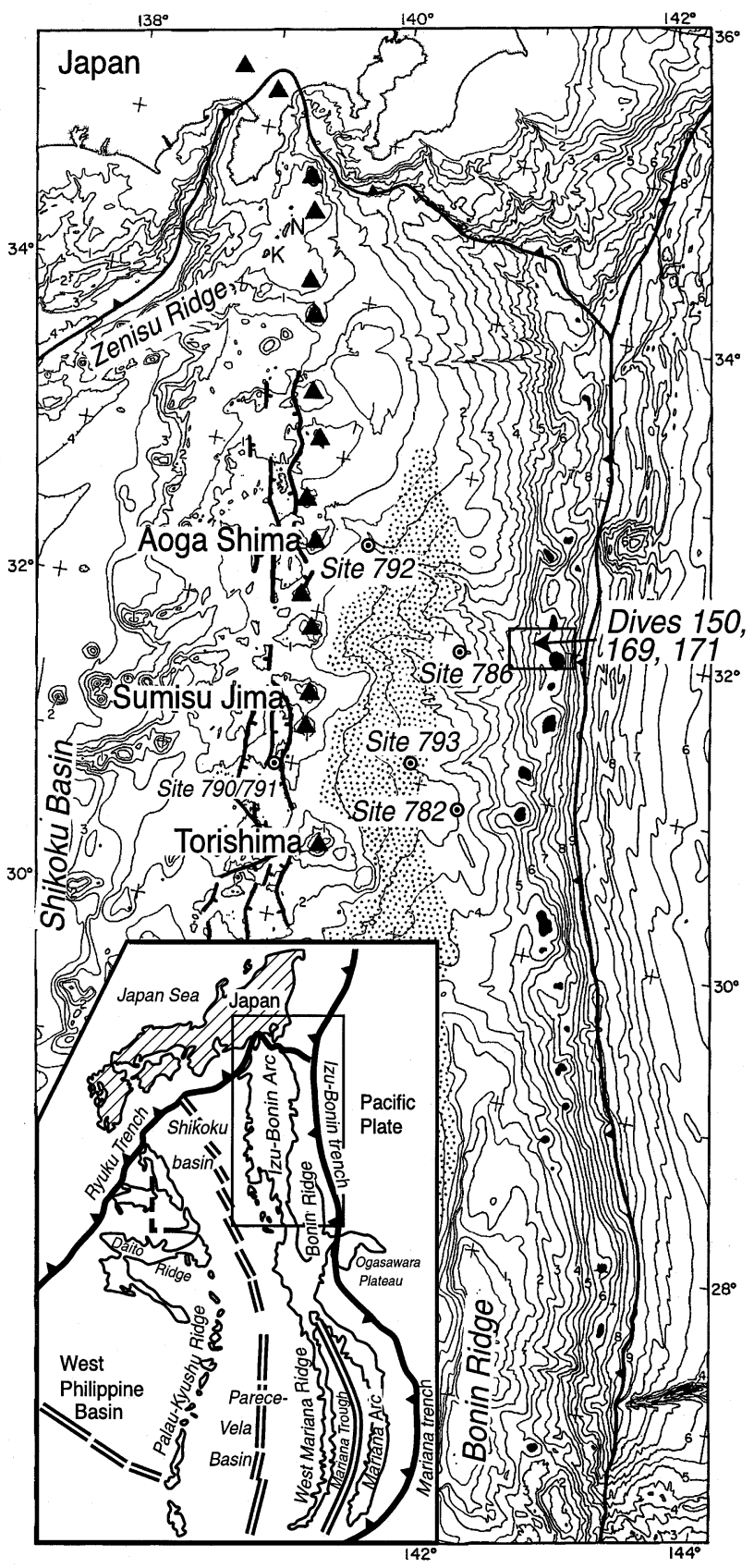

Fig. 1. Bathymetry (500 m contour intervals, labeled every $\mathrm{km}$ ) of the Izu-Bonin arc-trench system modified after Taylor [6]. Barbed heavy lines locate trench axes, filled bathymetric contours locate serpentinite seamounts on the trench inner slope, filled triangles locate frontal arc volcanoes, ticked heavy lines locate active normal faults and the thickly sedimented forearc basin is stippled. ODP drill sites are numbered and an arrow points to the dive area on the trench slope at $32^{\circ} \mathrm{N}$. A box shows the location of Fig. 2. The inset shows simplified tectonic setting and location, basins and ridges are outlined by the $4 \mathrm{~km}$ bathymetric contour, except for the Izu-Bonin arc, West Mariana Ridge and Mariana arc, which are outlined by the $3 \mathrm{~km}$ contour. 

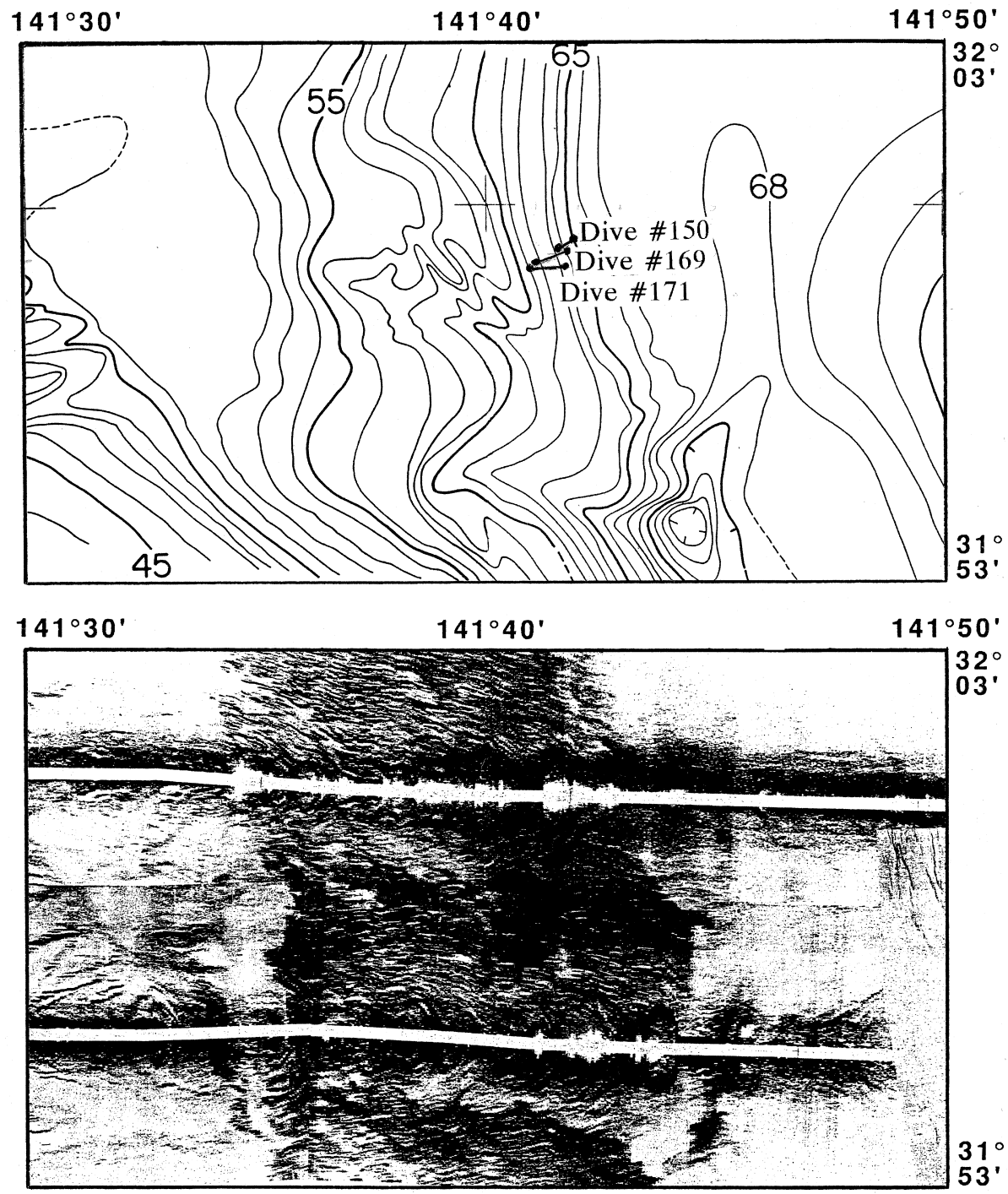

Fig. 2. SeaMARC II bathymetry ( $100 \mathrm{~m}$ contours, top) and acoustic imagery (bottom) of the Izu-Bonin trench inner slope at $32^{\circ} \mathrm{N}$ (see Fig. 1 for location). On the acoustic image, note the highly reflective slope between 5200 and $6700 \mathrm{~m}$, where seismic reflection records also indicate that arc basement is exposed. Locations of the dives are marked with heavy lines.

spaced, long-lived centers, but arc tholeiites have also occasionally intruded the forearc [7]. The present rifting of the central Izu-Bonin arc (including Sumisu Rift) began about 2-3 Ma and extends from $27.5^{\circ}$ to $33.5^{\circ} \mathrm{N}$ (Fig. 1). The Sumisu Rift at ODP Sites 790 and 791 is floored with synrift volcanics that are geochemically distinct from contemporary arc volcanics. The oldest $(>1.1$ $\mathrm{Ma})$ to the youngest (Holocene) Sumisu Rift lavas are backarc basin basalts, whereas pre- and syn- rift arc volcanism is mostly low $\mathrm{K}$, subalkaline rhyolite and andesite.

The basement of the Izu-Bonin forearc area was studied during the drilling programs of ODP Legs 125 and 126 (Fig. 1). At Site 786 $\left(31^{\circ} 52^{\prime} \mathrm{N}\right)$, low $\mathrm{Ca}$ boninites and bronzite andesites overlain by intermediate $\mathrm{Ca}$ boninites, bronzite andesites and a fractionated series of andesites, dacites and rhyolites were recovered from a core that penetrated to $661 \mathrm{~m}$ [8]. Site 786 is 
Table 1

Description of samples collected from the inner trench slope

\begin{tabular}{|c|c|c|c|c|c|}
\hline Sample & Lithology & Phenocrysts & Groundmass/texture & Alteration & Water depth \\
\hline $150-01 \mathrm{a}$ & $\begin{array}{l}\text { Devitrified lava clast } \\
\text { in breccia }\end{array}$ & $\begin{array}{l}\text { Acicular, fine } \\
\text { plag, cpx }\end{array}$ & $90 \%$ glass, intersertal & $\begin{array}{l}\text { Actinolite, } \\
\text { chlorite }\end{array}$ & $6491 \mathrm{~m}$ \\
\hline $150-01 b$ & $\begin{array}{l}\text { Devitrified lava clast } \\
\text { in breccia }\end{array}$ & Absent & Vitrophyric & None & $6491 \mathrm{~m}$ \\
\hline $150-02$ & Diabase & Absent & $\begin{array}{l}\text { Fine grained, } 40 \% \mathrm{cpx}, 50 \% \text { plag, } \\
10 \% \text { oxides }\end{array}$ & $\begin{array}{l}\text { Actinolite, } \\
\text { chlorite }\end{array}$ & $6420 \mathrm{~m}$ \\
\hline $150-03$ & Devitrified basalt & $\begin{array}{l}<5 \% \text { cpx },<5 \% \\
\text { plag }\end{array}$ & Vitrophyric & None & $6390 \mathrm{~m}$ \\
\hline 169-01a & Fine grained basalt & $5 \%$ plag, $5 \%$ cpx & Crypto-crystalline & None & $6192 \mathrm{~m}$ \\
\hline $169-01 b$ & Fine grained basalt & $5 \%$ plag, $5 \%$ cpx & Crypto-crystalline & None & $6192 \mathrm{~m}$ \\
\hline BT-1 & Diabase & None & $\begin{array}{l}\text { Ophitic, } 60 \% \text { plag, } 30 \% \text { cpx, } \\
\sim 1 \% \text { oxide, } \sim 1 \% \text { olivine }\end{array}$ & $\begin{array}{l}\text { Chlorite } \\
\text { replacing cpx }\end{array}$ & $6400-6700 \mathrm{~m}$ \\
\hline BT-2 & Diabase & None & $\begin{array}{l}\text { Ophitic, } 55 \% \text { plag, } 43 \% \text { cpx, } \\
2 \% \text { oxide, } \sim 1 \% \text { olivine }\end{array}$ & $\begin{array}{l}\text { Chlorite } \\
\text { replacing cpx }\end{array}$ & $6400-6700 \mathrm{~m}$ \\
\hline
\end{tabular}

located on the forearc basement high, the southward continuation of which is exposed above sea level in the Ogasawara (or Bonin) Islands (Fig. 1), the type locality for boninites. New ${ }^{40} \mathrm{Ar} /{ }^{39} \mathrm{Ar}$ ages, consistent with biostratigraphic ages of immediately overlying sediments, indicate that the Site 786 basement formed by at least $47-45 \mathrm{Ma}$ [9].

\section{Petrology and geochemistry of inner trench slope samples}

\subsection{Dive descriptions and sample petrography}

Samples described in this study were collected during two research cruises of the Japan Marine Science and Technology Center (JAMSTEC) ship R/V Yokosuka with the Shinkai 6500 submersible. Three manned submersible dives were completed and six samples were collected from the trench inner slope in the region of $31^{\circ} 59^{\prime} \mathrm{N}$ and $141^{\circ} 41^{\prime}-141^{\circ} 42^{\prime} \mathrm{E}$ (Figs. 1 and 2) from water depths of 6499-6190 m. Recovery of more samples was inhibited by the cohesiveness of the outcrop. Complete dive descriptions can be found in [5].

Outcrop is excellent and ranges from well bedded flows that dip $-20^{\circ}$ into the slope to steep cliff faces (tens of meters) with megascale layering striking approximately $\mathrm{N} 30^{\circ} \mathrm{W}$ and dipping gently southwest into the cliff. Columnar jointing in cliff faces is common, as are megascale $(1-4 \mathrm{~m})$ pillow structures. Steep cliffs alternate with flat muddy steps and may represent successive trench-parallel fault blocks [5]. No exposures of plutonic rocks were observed.

Samples collected during the dives consist of fine diabase (samples 150-01, 150-02), devitrified glass (sample 150-03) and basalt (sample 169-01) (Table 1). Two additional diabase samples (BT-1 and BT-2, Table 1) are included in this study. These samples were recovered on a R/V Kana Keoki cruise (KK84-04-27 Leg 3) in 1984 by the second author while dredging the trenchward side of Myojin forearc seamount at $31^{\circ} 58^{\prime} \mathrm{N}, 141^{\circ} 56$ $57^{\prime} \mathrm{E}$, just east of the edge of Fig. 2. The dredge recovered dominantly serpentinized ultramafic rocks plus the two diabase samples analyzed here. It is not known whether the diabase was incorporated from deeper levels by the rising serpentinite or whether they were transported down Aoga Shima canyon and up and over the crest of the seamount.

Petrographic characteristics of the samples are summarized in Table 1. In general, phenocrysts are rare to absent and all samples have some alteration, from solely devitrification at the lower end to lower greenschist facies at the upper end. 
Table 2

Geochemical analyses of samples from the Izu-Bonin inner trench slope

\begin{tabular}{|c|c|c|c|c|c|c|c|c|}
\hline \multirow{3}{*}{$\begin{array}{l}\text { Sample: } \\
\text { Description: }\end{array}$} & \multicolumn{2}{|c|}{ Myojin Seamount } & \multicolumn{4}{|l|}{ Dive \#150 } & \multicolumn{2}{|c|}{ Dive \#169 } \\
\hline & BT-1 & BT-2 & $150-01 \mathrm{a}$ & $150-01 b$ & $150-02$ & $150-03$ & $169.01 \mathrm{a}$ & $169.01 \mathrm{~b}$ \\
\hline & $\begin{array}{l}\text { Coarse gr. } \\
\text { diabase }\end{array}$ & $\begin{array}{l}\text { Coarse gr. } \\
\text { diabase }\end{array}$ & $\begin{array}{l}\text { Devitrified } \\
\text { basalt clast }\end{array}$ & $\begin{array}{l}\text { Devitrified } \\
\text { basalt clast }\end{array}$ & $\begin{array}{l}\text { Fine gr. } \\
\text { diabase }\end{array}$ & $\begin{array}{l}\text { Devitrified } \\
\text { glass }\end{array}$ & $\begin{array}{l}\text { Fine gr. } \\
\text { basalt }\end{array}$ & $\begin{array}{l}\text { Fine gr. } \\
\text { basalt }\end{array}$ \\
\hline Minerals: & $\mathrm{cp}, \mathrm{op}, \mathrm{pl}, \mathrm{ol}$ & $\mathrm{cp}, \mathrm{pl}, \mathrm{ol}, \mathrm{opq}$ & $\mathrm{pl}, \mathrm{cp}$ & - & $\mathrm{cp}, \mathrm{pl}$, opq & $\mathrm{pl}, \mathrm{cp}$ & $\mathrm{pl}, \mathrm{cp}$ & $\mathrm{pl}, \mathrm{cp}$ \\
\hline $\mathrm{SiO}_{2}$ & 50.50 & 51.52 & 52.73 & 51.3 & 52.31 & 49.92 & 50.46 & 49.95 \\
\hline $\mathrm{TiO}_{2}$ & 0.67 & 1.19 & 1.80 & 1.12 & 1.44 & 1.71 & 0.83 & 0.82 \\
\hline $\mathrm{Al}_{2} \mathrm{O}_{3}$ & 15.33 & 13.98 & 13.89 & 14.23 & 13.95 & 13.67 & 16.21 & 16.17 \\
\hline $\mathrm{FeO}^{\mathrm{a}}$ & 8.63 & 11.51 & 13.17 & 12.23 & 12.97 & 14.03 & 8.77 & 8.74 \\
\hline $\mathrm{MnO}$ & 0.18 & 0.26 & 0.29 & 0.23 & 0.23 & 0.25 & 0.16 & 0.17 \\
\hline $\mathrm{MgO}$ & 9.73 & 8.15 & 5.96 & 7.48 & 7.87 & 6.55 & 7.94 & 7.85 \\
\hline $\mathrm{CaO}$ & 12.72 & 10.31 & 7.68 & 10.01 & 6.42 & 9.68 & 12.33 & 12.53 \\
\hline $\mathrm{Na}_{2} \mathrm{O}$ & 1.69 & 2.46 & 3.03 & 2.48 & 3.08 & 3.26 & 2.31 & 2.3 \\
\hline $\mathrm{K}_{2} \mathrm{O}$ & 0.08 & 0.08 & 0.42 & 0.14 & 0.2 & 0.19 & 0.29 & 0.27 \\
\hline $\mathrm{P}_{2} \mathrm{O}_{5}$ & 0.04 & 0.10 & 0.15 & 0.08 & 0.13 & 0.12 & 0.06 & 0.05 \\
\hline Total & 99.57 & 99.55 & 99.12 & 99.31 & 98.6 & 99.39 & 99.35 & 98.85 \\
\hline $\mathrm{Mg} /(\mathrm{Mg}+\mathrm{Fe})$ & 66.8 & 55.8 & 44.7 & 52.2 & 52.0 & 45.4 & 61.7 & 61.6 \\
\hline $\mathrm{Ni}$ & 115 & 62 & 43 & 42 & 44 & 30 & 98 & 109 \\
\hline $\mathrm{Cr}$ & 407 & 152 & 147 & 59 & 95 & 50 & 353 & 353 \\
\hline $\mathrm{Sc}$ & 44 & 49 & 50 & 50 & 51 & 52 & 48 & 46 \\
\hline $\mathrm{V}$ & 264 & 355 & 431 & 360 & 384 & 496 & 288 & 276 \\
\hline $\mathrm{Rb}$ & 0.7 & 0.7 & 7.6 & 2.7 & 1.1 & 1.2 & 7.0 & 5.0 \\
\hline $\mathrm{Sr}$ & 54 & 70 & 81 & 74 & 80 & 80 & 79 & 78 \\
\hline $\mathrm{Zr}$ & 37 & 73 & 96 & 60 & 93 & 91 & 47 & 47 \\
\hline $\mathrm{Y}$ & 18 & 31 & 36 & 28 & 38 & 40 & 22 & 23 \\
\hline $\mathrm{Nb}$ & 0.4 & 0.8 & 2.0 & 1.3 & 1.1 & 1.1 & 4.3 & 2.1 \\
\hline $\mathrm{Ga}$ & 15 & 19 & 20 & 17 & 19 & 19 & 17 & 13 \\
\hline $\mathrm{Cu}$ & 125 & 144 & 38 & 119 & 96 & 97 & 133 & 146 \\
\hline $\mathrm{Zn}$ & 41 & 120 & 151 & 102 & 91 & 116 & 64 & 66 \\
\hline $\mathrm{Ba}$ & 1.5 & 4.2 & 6.9 & 5.4 & 5.2 & 3.0 & 4.0 & 2.0 \\
\hline $\mathrm{Th}$ & 0.04 & 0.07 & 0.18 & 0.2 & 0.12 & 0.11 & 0.08 & 0.05 \\
\hline $\mathrm{Hf}$ & 0.81 & 1.68 & 2.54 & 1.47 & 2.34 & 2.27 & 1.16 & 1.07 \\
\hline $\mathrm{Ta}$ & 0.04 & 0.07 & 0.15 & 0.1 & 0.11 & 0.1 & 0.04 & 0.04 \\
\hline $\mathrm{Rb}$ & 0.66 & 0.66 & 7.55 & 2.72 & 1.06 & 1.17 & 4.86 & 4.19 \\
\hline Cs & 0.02 & 0.01 & 0.41 & 0.15 & 0.02 & 0.01 & 0.14 & 0.12 \\
\hline $\mathrm{La}$ & 0.95 & 1.81 & 2.84 & 1.79 & 2.56 & 2.47 & 1.40 & 1.33 \\
\hline $\mathrm{Ce}$ & 2.73 & 5.84 & 9.08 & 5.29 & 8.19 & 7.81 & 3.99 & 3.77 \\
\hline $\operatorname{Pr}$ & 0.55 & 1.05 & 1.59 & 0.93 & 1.44 & 1.45 & 0.75 & 0.70 \\
\hline $\mathrm{Nd}$ & 3.05 & 6.16 & 8.96 & 5.28 & 8.40 & 8.40 & 4.31 & 4.20 \\
\hline $\mathrm{Sm}$ & 1.41 & 2.66 & 3.69 & 2.33 & 3.58 & 3.61 & 1.84 & 1.83 \\
\hline $\mathrm{Eu}$ & 0.60 & 1.01 & 1.39 & 0.93 & 1.29 & 1.36 & 0.79 & 0.77 \\
\hline $\mathrm{Gd}$ & 2.06 & 3.59 & 4.88 & 3.28 & 5.03 & 5.04 & 2.77 & 2.75 \\
\hline $\mathrm{Tb}$ & 0.43 & 0.76 & 1.00 & 0.69 & 1.01 & 1.04 & 0.54 & 0.54 \\
\hline Dy & 2.95 & 5.33 & 6.68 & 4.82 & 6.88 & 7.06 & 3.84 & 3.81 \\
\hline Ho & 0.66 & 1.15 & 1.41 & 1.04 & 1.50 & 1.56 & 0.85 & 0.85 \\
\hline $\mathrm{Er}$ & 2.00 & 3.52 & 4.25 & 3.19 & 4.63 & 4.66 & 2.42 & 2.44 \\
\hline $\mathrm{Tm}$ & 0.28 & 0.49 & 0.60 & 0.45 & 0.65 & 0.67 & 0.36 & 0.35 \\
\hline $\mathrm{Yb}$ & 1.70 & 3.17 & 3.77 & 2.79 & 3.98 & 4.14 & 2.21 & 2.25 \\
\hline $\mathrm{Lu}$ & 0.27 & 0.48 & 0.61 & 0.44 & 0.61 & 0.65 & 0.35 & 0.35 \\
\hline
\end{tabular}

$\mathrm{cp}=$ clinopyroxene, $\mathrm{opq}=$ opaque minerals, $\mathrm{pl}=$ plagioclase, $\mathrm{ol}=$ olivine

${ }^{a} \mathrm{All} \mathrm{Fe}$ as $\mathrm{FeO}$. 

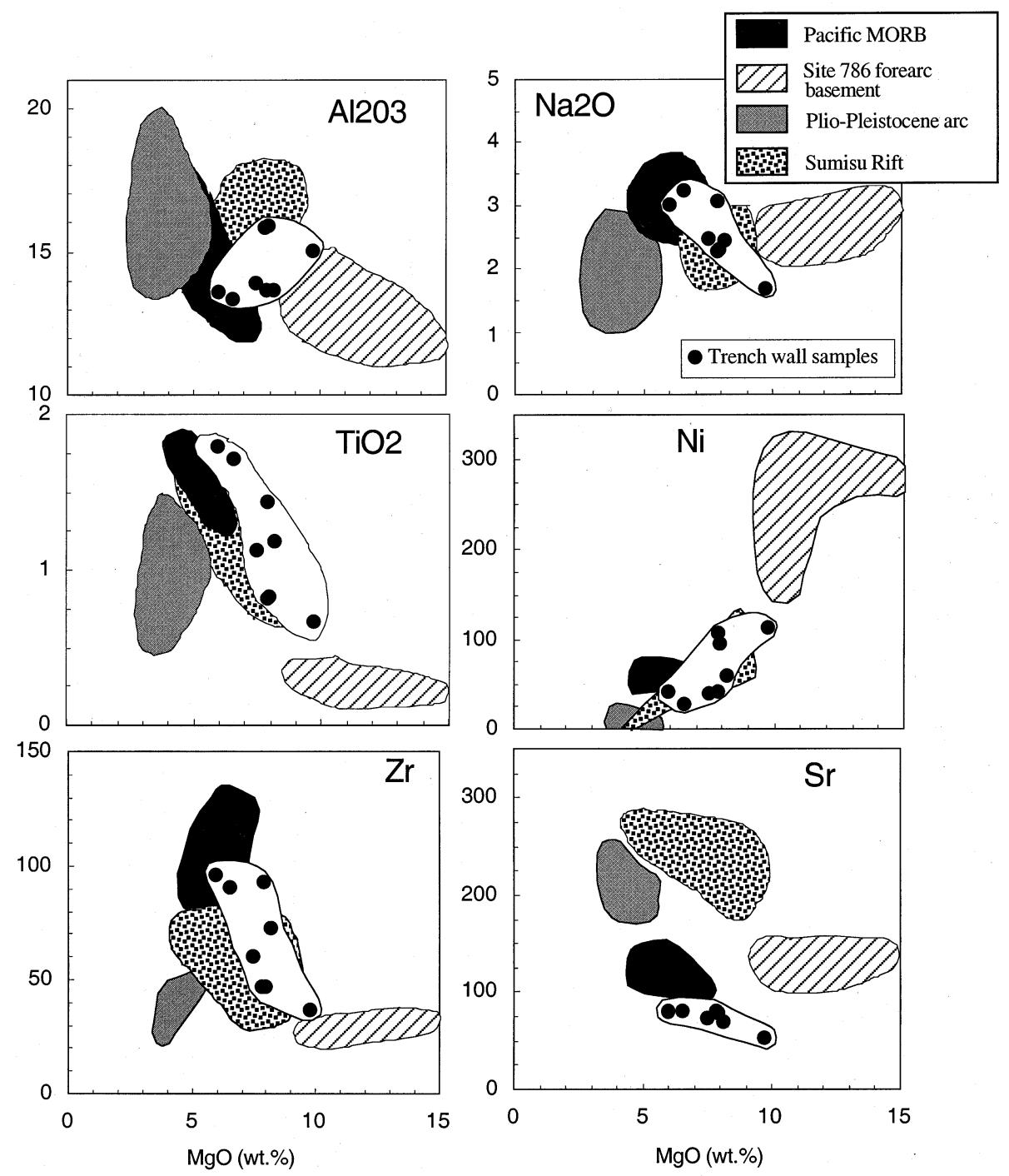

Fig. 3. Variation diagrams of selected major and trace elements vs. $\mathrm{MgO}$ for the inner trench slope samples. Also included for comparison are Pacific plate MORB [16], Site 786 boninites [8,13], basalts from the Quaternary arc [14,15] and basalts from the Sumisu Rift [17].

\subsection{Analytical methods}

Samples were analyzed for major elements and $\mathrm{Ni}, \mathrm{Cr}, \mathrm{Sc}, \mathrm{V}, \mathrm{Rb}, \mathrm{Sr}, \mathrm{Y}, \mathrm{Nb}, \mathrm{Zr}, \mathrm{Ga}, \mathrm{Cu}$ and $\mathrm{Zn}$ by a Rigaku 3370 XRF spectrometer at the Washington State University GeoAnalytical Lab according to the procedures of Johnson et al. [10]. Precision was tested by multiple analyses of a single specimen. Major element precision is $<2 \%$ of the absolute abundance. Trace element precision is $<5 \%$ except for $\mathrm{Rb}$ and $\mathrm{Nb}$, which are $10 \%$ in low abundance samples. The rare-earth elements (REE) and trace elements $\mathrm{Ba}, \mathrm{Th}, \mathrm{Hf}, \mathrm{Ta}, \mathrm{U}, \mathrm{Pb}$, $\mathrm{Rb}$ and $\mathrm{Cs}$ were also analyzed at Washington State University by a Sciex Elan model 250 ICPMS equipped with a Babington nebulizer, watercooled spray chamber and Brooks mass flow controller. The precision on in-house standards 

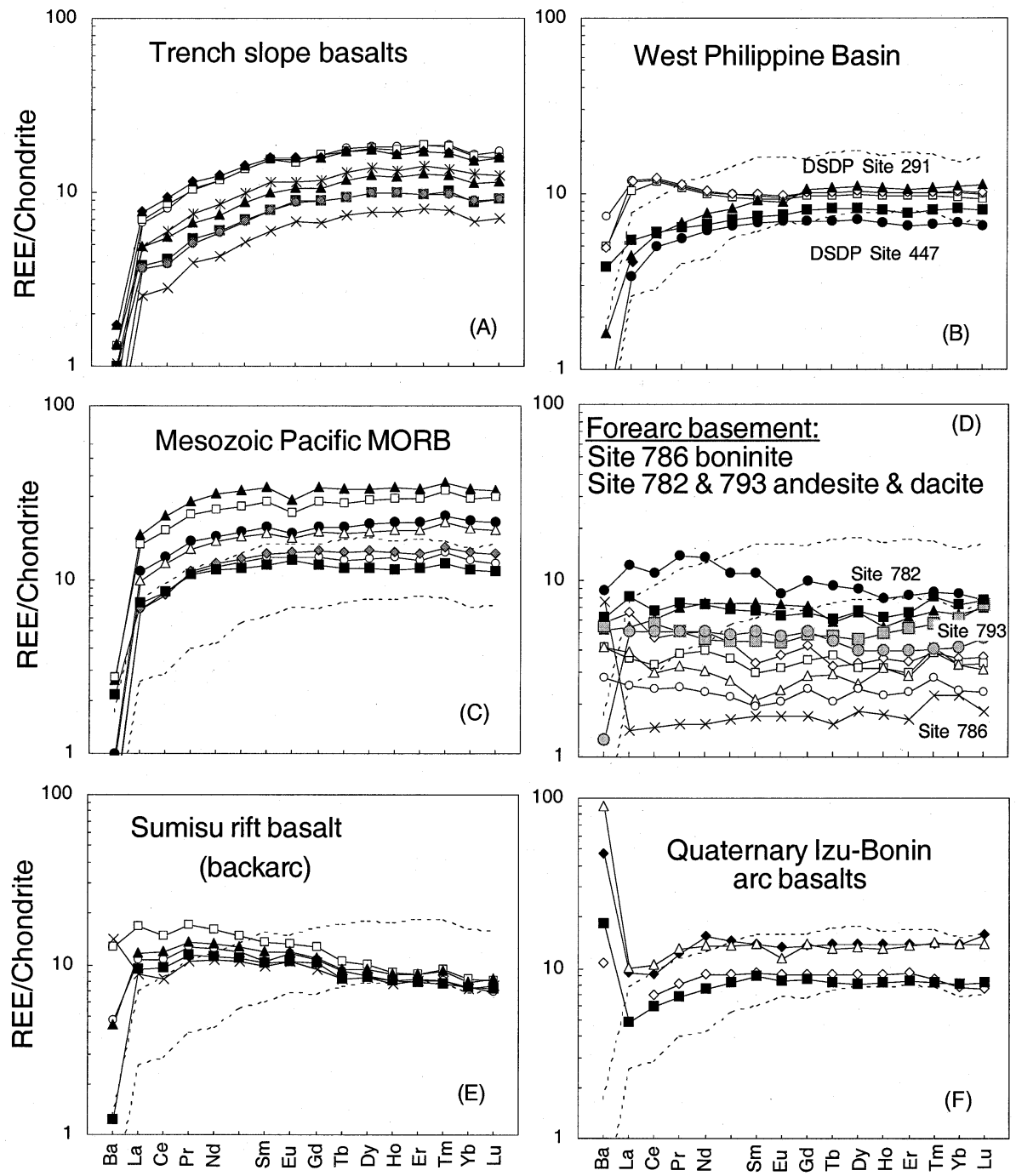

Fig. 4. REE patterns of (A) inner trench slope samples, (B) West Philippine Basin [20], (C) Mesozoic Pacific MORB [16], (D) Forearc basement drilled by ODP at Sites 786, 782 and 793B [13,18,19], (E) Sumisu Rift [17] and (F) active arc basalts from the Shichito Ridge and Torishima knoll [15,17]. Normalization values are from Taylor and McLennan [39].

BCR-P basalt is better than $1.5 \%$ for $\mathrm{Ce}, \mathrm{Pr}, \mathrm{Nd}$, $\mathrm{Gd}, \mathrm{Tb}, \mathrm{Dy}, \mathrm{Ho}, \mathrm{Er}, \mathrm{Tm}, \mathrm{Yb}, \mathrm{Y}$ and Hf, better than $2.5 \%$ for $\mathrm{Ba}, \mathrm{La}, \mathrm{Sm}, \mathrm{Eu}, \mathrm{Lu}, \mathrm{Rb}, \mathrm{Y}$ and $\mathrm{Nb}$, better than $3.5 \%$ for $\mathrm{Ta}$, $\mathrm{Cs}$ and $\mathrm{Pb}$ and better than $10 \%$ for Th and U. Reported ICP-MS detection limits are $0.1-0.5$ times chondrite values (Charles Knaack, personal communication).

Isotope analyses were performed at the University of Hawaii. Forty-sixty mg of sample powders was processed from acid-washed rock chips and analyzed for $\mathrm{Sr}, \mathrm{Nd}$ and $\mathrm{Pb}$ isotopes in the SOEST Mass Spectrometry Lab. Lead was purified on anion-exchange resin using $\mathrm{HBr}-\mathrm{HNO}_{3}$ chemistry under class- 100 conditions. The non- $\mathrm{Pb}$ fraction was collected and processed sequentially to isolate $\mathrm{Sr}$ and the $\mathrm{REE}$ on $\mathrm{HCl}$ columns. This was followed by $\mathrm{Nd}$ purification from other REE on cation resin using 2-methyllactic acid. 
Table 3

Isotopic analyses of selected samples from the Izu-Bonin inner trench slope

\begin{tabular}{llcc}
\hline & Myojin Seamount & Dive \#150 & Dive \#169 \\
\hline Sample & BT-1 & $150-02$ & $169.01 \mathrm{a}$ \\
Description & Coarse gr. diabase & Fine gr. diabase & Fine gr. basalt \\
\hline $\mathrm{Pb}(\mathrm{ppm})$ & 0.093 & 0.196 & 0.139 \\
${ }^{206} \mathrm{~Pb} /{ }^{204} \mathrm{~Pb}$ & 18.21 & 18.42 & 18.46 \\
${ }^{207} \mathrm{~Pb} /{ }^{204} \mathrm{~Pb}$ & 15.51 & 15.53 & 15.50 \\
${ }^{208} \mathrm{~Pb} /{ }^{204} \mathrm{~Pb}$ & 38.03 & 38.16 & 38.04 \\
${ }^{143} \mathrm{Nd} / 144 \mathrm{Nd}$ & 0.513077 & 0.513057 & 0.513063 \\
$\varepsilon_{\mathrm{Nd}}$ & 8.5 & 8.1 & 8.3 \\
${ }^{87} \mathrm{Sr} /{ }^{86} \mathrm{Sr}$ (unleached) & 0.70346 & 0.70428 & 0.70359 \\
${ }^{87} \mathrm{Sr} /{ }^{86} \mathrm{Sr}$ (leached) & 0.70333 & 0.70373 & 0.70321 \\
\hline
\end{tabular}

Leached $\mathrm{Sr}$ analyses were obtained by subjecting a split of the sample powders to a harsh, multi-step technique using repeated attacks of $6 \mathrm{~N} \mathrm{HCl}$ during sonification, in order to remove a seawater $\mathrm{Sr}$ signature from altered rocks [11].

Samples were analyzed on a Micromass Sector mass spectrometer in multicollector mode. Sr was analyzed in dynamic mode, loading approximately $100 \mathrm{ng} \mathrm{Sr}$ onto finely ground tantalum powder on a tungsten filament. $\mathrm{Nd}(\sim 25 \mathrm{ng})$ and $\mathrm{Pb}(\sim 6-8 \mathrm{ng})$ were analyzed using silica-gel phosphoric acid on a $\mathrm{Re}$ filament, $\mathrm{Nd}$ in dynamic and $\mathrm{Pb}$ in static mode.

Isotopic fractionation factors are ${ }^{148} \mathrm{Nd} /{ }^{144} \mathrm{Nd}=$ $0.241572,{ }^{86} \mathrm{Sr} /{ }^{88} \mathrm{Sr}=0.1194$. The lab's value for LaJolla $\mathrm{Nd}$ is ${ }^{143} \mathrm{Nd} /{ }^{144} \mathrm{Nd}=0.511843 \pm 0.000009$, or $\sim 0.15$ epsilon units, and for SRM 987 , it is ${ }^{87} \mathrm{Sr} /{ }^{86} \mathrm{Sr}=0.71024 \pm 0.00002$ (both $2 \times$ S.D.). $\mathrm{Pb}$ isotopes are corrected for fractionation using the values of Todt [12] and the total ranges measured on NBS 981 are \pm 0.008 for ${ }^{206} \mathrm{~Pb} /{ }^{204} \mathrm{~Pb}$, 0.008 for ${ }^{207} \mathrm{~Pb} /{ }^{204} \mathrm{~Pb}$ and 0.030 for ${ }^{208} \mathrm{~Pb} /{ }^{204} \mathrm{~Pb}$. In-run errors for individual samples are less than the stated uncertainties on standards. Total procedural blanks are $<40 \mathrm{pg}$ for $\mathrm{Pb},<20 \mathrm{pg}$ for $\mathrm{Nd},<120 \mathrm{pg}$ for Sr. Zero-age epsilon $\mathrm{Nd}$ corresponds to ${ }^{143} \mathrm{Nd} /{ }^{144} \mathrm{Nd}=0.51264$ for ${ }^{147} \mathrm{Sm} /$ ${ }^{144} \mathrm{Nd}=0.1967$.

\subsection{Geochemistry}

Whole-rock compositions of the trench inner slope samples (Table 2) define a tholeiitic trend on an AFM diagram, with 8.5-14.0 wt\% (wt.\%)
FeO. They are all basaltic, except for sample 15001a, which is a basaltic andesite $\left(52.7 \% \mathrm{SiO}_{2}\right)$. They have low to moderate $\mathrm{Al}_{2} \mathrm{O}_{3}$ (13.5-16 wt.\%), moderate $\mathrm{MgO}\left(6-10\right.$ wt.\%) and $\mathrm{TiO}_{2}$ $(0.7-1.8$ wt. $\%)$ and low $\mathrm{K}_{2} \mathrm{O}(<0.5$ wt. $\%)$. They are distinctive in their extremely low Ba contents (1.5-7 parts per million (ppm)). None of the samples are boninitic. They bear no geochemical resemblance to the Eocene boninitic samples recovered just upslope from the forearc basement in Site 786 of ODP Leg 125. They also do not resemble tholeiitic basalts of the modern Izu-Bonin arc or backarc.

The relative variations of the major elements and some of the minor elements of the inner trench slope samples are plotted on $\mathrm{MgO}$ variation diagrams in Fig. 3. They are compared to forearc basement recovered at Site 786 of ODP Leg $125[8,13]$, basalts from the Quaternary IzuBonin arc [14,15], Pacific plate MORB [16] and basalts from the Sumisu Rift [17]. Although only data for $\mathrm{Al}_{2} \mathrm{O}_{3}, \mathrm{Na}_{2} \mathrm{O}, \mathrm{TiO}_{2}, \mathrm{Ni}, \mathrm{Zr}$ and $\mathrm{Sr}$ are shown, a decreasing $\mathrm{MgO}$ content in the trench slope samples correlates with increasing $\mathrm{K}_{2} \mathrm{O}$, $\mathrm{P}_{2} \mathrm{O}_{5}, \mathrm{TiO}_{2}, \mathrm{FeO}$ and $\mathrm{Na}_{2} \mathrm{O}$ and scattered $\mathrm{CaO}$, $\mathrm{Al}_{2} \mathrm{O}_{3}$ and $\mathrm{SiO}_{2}$. The compatible minor elements $\mathrm{Cr}$ and $\mathrm{Ni}$ decrease with decreasing $\mathrm{MgO}$, whereas the incompatible elements $\mathrm{Ba}, \mathrm{Zr}, \mathrm{Nb}, \mathrm{Rb}$ and $\mathrm{Y}$ increase with decreasing $\mathrm{MgO}$. Values of $\mathrm{Sr}$ increase slightly.

As seen in Fig. 3, these trench slope samples are distinct from the ODP Site 786 forearc basement samples. The latter have much more $\mathrm{MgO}$ and $\mathrm{SiO}_{2}$, lower $\mathrm{Al}_{2} \mathrm{O}_{3}, \mathrm{FeO}, \mathrm{TiO}_{2}$ and $\mathrm{P}_{2} \mathrm{O}_{5}$ but sim- 

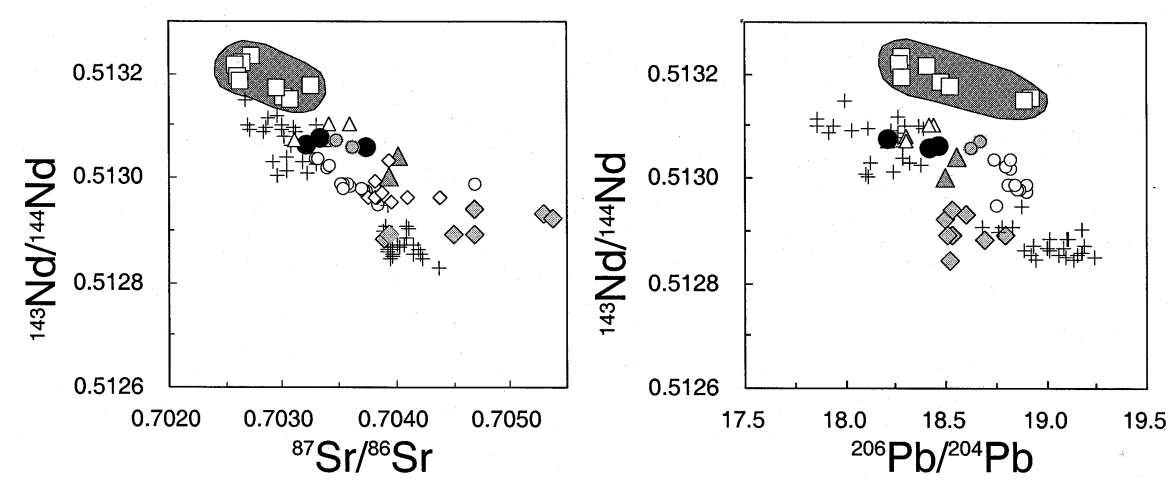

Trench slope samples
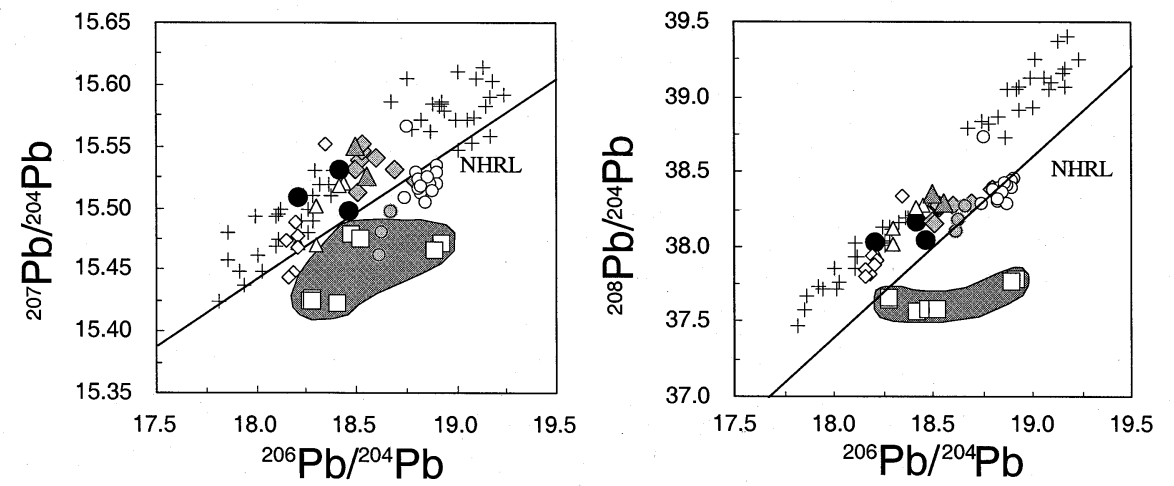

$\square$ Pacific MORB

+ Philippine Sea plate

$\triangle$ Plio-Pleistocene arc

- Site 786 forearc

basement (boninitic)

- Site 782 forearc

basement (tholeiitic)

$\diamond$ Site 793 forearc

basement

$\diamond$ Chichijima

$\triangle$ Hahajima

Fig. 5. Isotopic systematics (present-day ratios) for the inner trench slope samples compared to Pacific plate MORB [16], forearc basement drilled from ODP Site 786 [18], Site 792 [18] and Site 793 [19] (see Fig. 1), boninite from the islands of Chichijima [23] and Hahajima [22], Plio-Pleistocene Izu-Bonin arc volcanics from Torishima and Miyakejima volcanoes [14] and other Philippine Sea plate submarine lavas including the West Philippine, Parece Vela and Shikoku Basins [20,21] and the Sumisu Rift [40].

ilar $\mathrm{CaO}, \mathrm{Na}_{2} \mathrm{O}$ and $\mathrm{K}_{2} \mathrm{O}$. They are also distinctive in their trace elements: trench slope samples have lower $\mathrm{Ba}, \mathrm{Rb}, \mathrm{Sr}, \mathrm{Ni}$ and $\mathrm{Cr}$ and higher $\mathrm{Zr}$, $\mathrm{Y}$ and $\mathrm{Nb}$ than the boninite samples. The trench slope samples also do not look like modern-day arc magmas erupted from Izu-Bonin volcanoes. They have much lower $\mathrm{Sr}$ and higher $\mathrm{Ti}, \mathrm{Nb}, \mathrm{Ni}$ and $\mathrm{Cr}$. They do not show the marked enrichment in large-ion lithophile elements such as $\mathrm{K}, \mathrm{Rb}$ and Ba relative to MORB, nor other trace element characteristics typical of island arc tholeiites. They are quite depleted in $\mathrm{Ba}(1.5-7 \mathrm{ppm})$ and have low $\mathrm{Ba} / \mathrm{La}(1.2-3)$ and $\mathrm{Ti} / \mathrm{Zr}$ (93-112), more typical of MORB.

Chondrite-normalized REE patterns for the inner trench slope samples (Fig. 4) show depletion of the light REE and $\mathrm{Ba}$, with values of $\mathrm{La} / \mathrm{Yb}_{\mathrm{CN}}$ from 0.4 to 0.6 . The patterns for each of the samples are strikingly parallel, even for the samples dredged from Myojin forearc seamount. The samples do not have the typical enrichment of largeion lithophile elements (such as Ba) that is so characteristic of island arc magmas, including basalts from the Quaternary Izu-Bonin arc [14,15], boninites from the forearc basement $[13,18,19]$ and Neogene sills from the Mariana and Izu-Bonin forearcs [7]. They also do not share REE characteristics with backarc basin basalts of the Sumisu Rift [17] or the Shikoku Basin [5,20]. The REE patterns do, however, show similarities to Mesozoic Pacific MORB [16] and MORB from the West Philippine Basin [20], although the Pacific plate samples show flatter patterns with generally higher abundances for a given $\mathrm{MgO}$ content than the trench slope samples (Fig. 4). West Philippine Basin MORB sampled at Deep Sea Drilling Program Site 447 [20] have REE patterns most closely related to the trench slope samples. 


\section{Cross section of the Izu-Bonin arc at $32^{\circ} 15^{\prime} \mathrm{N}$}

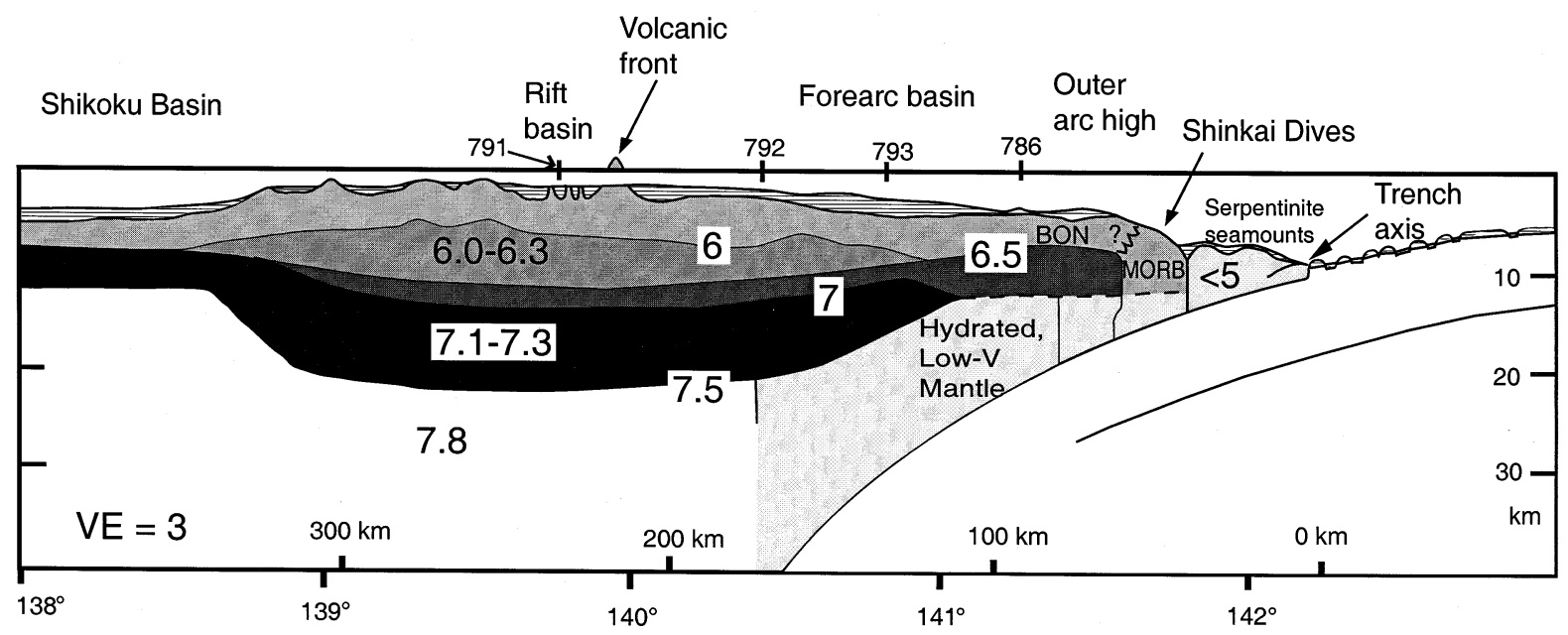

Fig. 6. Schematic west-east section across the Izu-Bonin arc-trench system after Suyehiro et al. [30]. Numbers 791, 792, 793 and 786 refer to ODP Sites (positions projected along strike). Large numbers are seismic velocities in $\mathrm{km} / \mathrm{s}$. BON region is boninitic crust sampled at Site 786, MORB region is mid-ocean ridge crust sampled by Shinkai dives.

One sample in particular, 21-1 (filled triangles in Fig. 4), has a pattern identical to several of the inner trench slope samples.

\subsection{Isotope geochemistry}

Strontium, neodymium and lead isotopes were analyzed on three of the Izu-Bonin trench slope samples (BT-1, 150-02 and 169-01a) (Table 3). The samples have a very consistent ${ }^{143} \mathrm{Nd} /{ }^{144} \mathrm{Nd}$ (0.513057-0.513077), but more variable ${ }^{87} \mathrm{Sr} /{ }^{86} \mathrm{Sr}$ (unleached samples: 0.70346-0.70428; leached samples: 0.70321-0.70373). Acid leaching to remove $\mathrm{Sr}$ added by seawater exchange significantly lowered $\mathrm{Sr}$ isotopic ratios. Lead isotopic ratios are fairly limited in range, with ${ }^{206} \mathrm{~Pb} /{ }^{204} \mathrm{~Pb}=18.21$ 18.46, ${ }^{207} \mathrm{~Pb} /{ }^{204} \mathrm{~Pb}=15.3-15.5$ and ${ }^{208} \mathrm{~Pb} /{ }^{204} \mathrm{~Pb}=$ 38.0-38.2.

The trench slope samples are compared to $\mathrm{Pa}$ cific plate MORB and a variety of Philippine Sea plate samples in Fig. 5. It is clear that the trench slope samples have a lower ${ }^{143} \mathrm{Nd} /{ }^{144} \mathrm{Nd}$ and higher ${ }^{207} \mathrm{~Pb} /{ }^{204} \mathrm{~Pb}$ and ${ }^{208} \mathrm{~Pb} /{ }^{204} \mathrm{~Pb}$ for a given ${ }^{206} \mathrm{~Pb} /$ ${ }^{204} \mathrm{~Pb}$ than Pacific plate MORB. They fall above the Northern Hemisphere reference line (NHRL), whereas Pacific plate MORB characteristically plot on or below this line [16]. Their values do fall on a trend that is characteristic of a variety of lavas from the Philippine Sea plate. These include MORB-type basalt from the West Philippine, Parece Vela and Shikoku Basins [20,21], as well as arc-related lavas from the Palau Kyushu ridge [21], the modern arc front [14] and forearc boninites $[18,19,22,23]$. This characteristic isotopic signature of Philippine Sea plate rocks is the same as that from Indian Ocean spreading ridges and is interpreted to be due to a shared asthenospheric mantle domain $[20,24]$. This Indian Ocean mantle domain is distinct from that of Pacific plate MORB [20,24].

Interestingly, although the trench slope samples shown in Fig. 5 are similar in $\mathrm{Pb}$ isotopic ratios to samples from the Quaternary arc [14,15] and some Philippine Sea plate MORB, they are distinct from boninitic and tholeiitic samples drilled during ODP Leg 125 (Sites 786 and 782). Leg 125 is located just $3 \mathrm{~km}$ shallower on the outer arc high east of the dive site (Fig. 1). These latter 
forearc basement samples plot on or just below the NHRL and lie very close to Pacific MORB mantle. Surprisingly, this odd isotopic signature is not shared by the subaerially exposed Eocene tholeiites and boninites from Hahajima [22] and Chichijima [23], also on the outer arc high. Pearce et al. [18] interpreted the $\mathrm{Pb}$ isotopic trends of Site 782 and 786 samples to be due to simple mixing between Pacific MORB mantle and Pacific hotspot component or volcanogenic sediment. Because they plot near the NHRL, they have little or no $\mathrm{Pb}$ derived from subducted pelagic sediment in their source. Hence, although spatially very close, the trench slope samples and the outer arc high forearc basement must be derived from very distinct sources.

\section{Discussion}

The presence of massive cliffs of pillowed lavas on the inner trench slope for at least 400 vertical meters (6100-6500 $\mathrm{m}$ water depth), and probably much more (Fig. 2), suggests that a good portion of the inner trench slope of the Izu-Bonin arc is not plutonic. These lavas are present at least 3000 $\mathrm{m}$ deeper than the volcanic material drilled from the outer arc high at ODP Site 786 (Fig. 1). More surprising, however, is the fact that these inner trench slope lavas have a geochemical signature that does not resemble those drilled lavas, nor do they resemble any typical arc magma. The REE patterns shown in Fig. 4 and other tectonic discrimination diagrams [5] argue that these trench slope samples are indistinguishable from N-MORB.

What is the origin of these N-MORB basalts? Specifically, were they accreted from the Pacific plate or are they a remnant of trapped Philippine Sea plate? In the Mariana arc, MORB-like lavas were also dredged from the outer forearc [25]. However, an $85 \mathrm{Ma}$ minimum K-Ar age and associated chert with Valanginian (131-138 Ma) and Albian (97-112 Ma) foraminifers conclusively supported an accreted origin for these rocks [26]. The chert and volcanic rocks are too old to have formed in situ or to be part of trapped West Philippine Basin crust. The samples discussed in this study have some similar characteristics to the Mariana MORB-like samples. However, there is no associated chert that could adequately discern rock ages. Ubiquitous glass devitrification and small sample size preclude analysis by $\mathrm{K}-\mathrm{Ar}$ or ${ }^{40} \mathrm{Ar} /{ }^{39} \mathrm{Ar}$. The alternative test, isotopic signatures, proved to be equally conclusive. Because Pacific plate MORB has distinctly different $\mathrm{Nd}$, $\mathrm{Sr}$ and $\mathrm{Pb}$ isotopic characteristics than almost all rocks from the Philippine Sea plate, the isotopic signature of the trench slope basalts analyzed herein provides a definitive test (Fig. 5). The isotopic characteristics of these basalts are distinct from those of Pacific plate MORB but overlap the fields for Philippine Sea plate rocks (Fig. 5).

This conclusion is significant for two reasons. Firstly, it constrains the physical structure and composition of the Izu-Bonin arc. To date, no trapped MORB oceanic crust has been recovered from drilling, on-land sampling or dredge hauls from the Izu-Bonin arc [27]. This led to the assumption that no pre-existing crust exists and that the entire arc infrastructure is made up of new, supra-subduction magmatic addition. Hence, interpretive cross sections of the arc do not take into account the fate of pre-existing crust [2830]. The discovery of trapped MORB on the inner trench slope suggests that the structure of the arc may need to be re-evaluated. This trapped crust may exist in other parts of the arc, but as with the inner trench slope, it may have been passed over by previous sampling campaigns. In Fig. 6, we present a simplified cross section of the Izu-Bonin arc that also shows the ODP drill sites projected along strike and the location of the MORB sampled by the Shinkai dives. We interpret the low velocities in the forearc above the subducted plate as hydrated low velocity mantle. In this interpretation, the crustal structure (thickness and velocities) beneath Site 786 is similar to that of oceanic crust and may represent an in situ ophiolite [27]. We do not know how much trapped MORB crust may exist. If the early arc formed under extension, much of the pre-existing oceanic crust could be rifted away, but some could be trapped within the arc as isolated crustal sections or slivers. These sections, with seismic velocities of 
$4.5-7 \mathrm{~km} / \mathrm{s}$, would be surrounded and/or intruded by new arc products from which they would be difficult to distinguish seismically.

If we assume that the early arc formed under extension and that much of the pre-existing MORB crust was rifted away to form the modern arc and forearc, then, the boundary between the boninitic forearc basement and the MORB basalts on the inner trench slope represents the eastern 'edge' of the Izu-Bonin arc. Where then is the western edge? Reconstruction of the early arc by closing of the rift and backarc basins suggests that the western edge should be just to the west of the Palau Kyushu ridge, north of the Daito Ridge (region enclosed by dashed right-angle triangle in Fig. 1). This East Amami Triangle oceanic basin is unsampled, but is likely to be the counterpart to the trapped MORB on the inner trench slope. Future drilling could test this hypothesis.

The presence of trapped oceanic crust also has implications for calculation of magma production rates in the early Izu-Bonin arc. Bloomer et al. [27] suggest that magma production rates were as high as $80-180 \mathrm{~km}^{3} / \mathrm{km} \mathrm{Ma}$ in the first $10-15$ million years of arc growth. These rates are much higher than those estimated for magma production at mature arcs and are comparable to crustal production rates at slow-spreading oceanic ridges. Their calculations are based on the assumption described above that the entire forearc represents arc-related magmatic addition and that there is no trapped oceanic crust. They assume a 200-300 km wide arc and a crustal thickness of $6 \mathrm{~km}$. If, however, a significant volume of trapped oceanic crust does exist within the forearc, magma production rates will necessarily be lower.

Models for the physical structure and composition of arc basement vary in their proportions of new magmatic addition, trapped oceanic crust and accreted oceanic sections. The velocity structure within $100 \mathrm{~km}$ of the volcanic front of the $\mathrm{Izu}-$ Bonin arc is consistent with the formation of felsic middle crust in the arc (Fig. 6) [30]. In contrast, trapped oceanic crust and a more mafic arc crust are inferred from velocity models to be present in the Aleutian arc [31,32] and have been found within uplifted sections of island arcs [33,34]. Accreted oceanic slivers [35,36] have been sampled within the Mariana forearc [26] and imaged within the Sulu forearc [37,38]. Clearly, the varying proportion of these three components must be determined before the physical structure of arcs and magma production rates within them can be adequately quantified.

\section{Conclusion}

Samples collected from 6200-6700 m water depth in the Izu-Bonin trench represent the first samples of trapped Philippine Sea plate oceanic crust discovered in the Izu-Bonin-Mariana arc to date. They have no affinity with the Eocene boninitic rocks drilled upslope in the forearc at ODP Site 786, nor are they similar to rocks from the active arc or backarc. Their geochemistry more closely resembles typical MORB. Isotopic and geochemical characteristics point to an origin within the Philippine Sea plate and preclude a genetic relationship to subducting Pacific plate crust. We suggest here that these N-MORB rocks represent a remnant piece of Philippine Sea plate oceanic crust that was unaffected by arc magmatism. They represent pre-existing crust that may be interspersed throughout the forearc with unknown extent. They require that models for the formation of intra-oceanic arc crust account for pre-existing oceanic crust and that estimates of arc magma production rates are lowered accordingly.

\section{Acknowledgements}

This research was conducted under the auspices of the UJNR deep-sea research program with funding from JAMSTEC for Japanese participants, ship time and submersible dives and funding from NOAA for US participants travel and analytical support. We thank the captain and crew of R/V Yokosuka and the pilots of Shinkai 6500 for their excellent services. Additional support from NSF to B. Taylor funded the isotopic analyses.[CL] 


\section{References}

[1] E. Honza and K. Tamaki, The Bonin Arc, in: A.E.M. Nairn, F.G. Stehli and S. Uyeda (Eds.), The Ocean Basins and Margins, The Pacific Ocean 7, pp. 459-502, Plenum Press, New York, 1985.

[2] R. Horine, G. Moore and B. Taylor, Structure of the outer Izu-Bonin forearc from reflection seismic profiling and gravity modeling, in: P. Fryer, J.A. Pearce and L.B. Stokking (Eds.), Proceedings of the Ocean Drilling Program 125, Initial Reports, Ocean Drilling Program, College Station, TX, 1990, pp. 81-94.

[3] D.M. Hussong and S. Uyeda, Tectonic processes and the history of the Mariana arc: a synthesis of the results of Deep Sea Drilling Project Leg 60, in: D.M. Hussong and S. Uyeda (Eds.), Initial Reports of the Deep Sea Drilling Program 60, Washington, DC, 1981, pp. 909-929.

[4] S.H. Bloomer, R.L. Fisher, Petrology and geochemistry of igneous rocks from the Tonga trench - a non-accreting plate boundary, J. Geol. 95 (1987) 469-495.

[5] S.M. DeBari, B. Taylor, K. Fujioka, MORB-type basalts on the inner trench wall of the Izu-Bonin trench-Accreted Pacific plate or pre-existing crust?, JAMSTEC J. Deep Sea Res. 11 (1995) 363-378.

[6] B. Taylor, Rifting and the volcanic-tectonic evolution of the Izu-Bonin-Mariana arc, in: B. Taylor and K. Fujioka (Eds.), Proceedings of the Ocean Drilling Program, Scientific Results, 126, Ocean Drilling Program, College Station, TX, 1992, pp. 627-651.

[7] R.N. Taylor, M.S. Marlow, L.E. Johnson, B. Taylor, S.H. Bloomer, J.G. Mitchell, Intrusive volcanic rocks in western Pacific forearcs, in: B. Taylor and J. Natland (Eds.), Active Margins and Marginal Basins of the Western Pacific, American Geophysical Union Geophysical Monograph 88 (1995) 31-43.

[8] R.J. Arculus, J.A. Pearce, B.J. Murton and S.R. van der Laan, Igneous stratigraphy and major-element geochemistry of Holes 786A and 786B, in: P. Fryer, J.A. Pearce and L.B. Stokking (Eds.), Proceedings of the Ocean Drilling Program, Scientific Results, 125, Ocean Drilling Program, 1992, pp. 143-169.

[9] M.A. Cosca, R.J. Arculus, J.A. Pearce, J.G. Mitchell, ${ }^{40} \mathrm{Ar} /{ }^{39} \mathrm{Ar}$ and $\mathrm{K}-\mathrm{Ar}$ geochronological age constraints for the inception and early evolution of the Izu-Bonin-Mariana arc system, Isl. Arc 7 (1998) 579-595.

[10] D.M. Johnson, P.R. Hooper and R.M. Conrey, XRF analysis of rocks and minerals for major and trace elements on a single low dilution Li-tetraborate fused bead, Adv. X-ray Anal. 41 (in press).

[11] J.J. Mahoney, K.J. Spencer, Isotopic evidence for the origin of the Manihiki and Ontong Java oceanic plateaus, Earth Planet. Sci. Lett. 104 (1991) 196-210.

[12] W. Todt, R.A. Cliff, A. Hanser and A.W. Hoffman, Evaluation of a ${ }^{202} \mathrm{~Pb}^{205} \mathrm{~Pb}$ double spike for high-precision lead isotope analysis, in: Earth Processes: Reading the Isotopic Code, American Geophysical Union Geophysical Monograph 95 (1996) 429-437.
[13] B.J. Murton, D.W. Peate, R.J. Arculus, J.A. Pearce and S. van der Laan, Trace-element geochemistry of volcanic rocks from Site 786: the Izu-Bonin forearc, in: P. Fryer, J.A. Pearce and L.B. Stokking (Eds.), Proceedings of the Ocean Drilling Program, Scientific Results, 125, College Station, TX, 1992, pp. 211-235.

[14] J.B. Gill, R.N. Hiscott, P. Vidal, Turbidite geochemistry and evolution of the Izu-Bonin arc and continents, Lithos 33 (1994) 135-168.

[15] Y. Ikeda, M. Yuasa, Volcanism in nascent back-arc basins behind the Shichito Ridge and adjacent areas in the Izu-Ogasawara arc, northwest Pacific: Evidence for mixing between E-type MORB and island arc magmas at the initiation of back-arc rifting, Contrib. Mineral. Petrol. 101 (1989) 377-393.

[16] P.E. Janney, P.R. Castillo, Geochemistry of Mesozoic Pacific mid-ocean ridge basalt: Constraints on melt generation and the evolution of the Pacific upper mantle, J. Geophys. Res. 102 (B3) (1997) 5207-5229.

[17] J.B. Gill, C. Seales, P. Thompson, A.G. Hochstaedter and C. Dunlap, Petrology and geochemistry of Pliocene-Pleistocene volcanic rocks from the Izu arc, Leg 126, in: B. Taylor and K. Fujioka (Eds.), Proceedings of the Ocean Drilling Program, Scientific Results, 126, Ocean Drilling Program, College Station, TX, 1992, pp. 383-404.

[18] J.A. Pearce, M.F. Thirlwall, G. Ingram, B.J. Murton, R.J. Arculus and S.R. van der Lan, Isotopic evidence for the origin of boninites and related rocks drilled in the IzuBonin (Ogasawara) forearc, Leg 125, in: P. Fryer, J.A. Pearce and L. Stokking (Eds.), Proceedings of the Ocean Drilling Program, Scientific Results, 125, Ocean Drilling Program, College Station, TX, 1992, pp. 237-261.

[19] R.N. Taylor, H. Lapierre, P. Vidal, R.W. Nesbitt and I.W. Croudace, Igneous geochemistry and petrogenesis of the Izu-Bonin forearc basin, in: B. Taylor and K. Fujioka (Eds.), Proceedings of the Ocean Drilling Program, Scientific Results, 126, Ocean Drilling Program, College Station, TX, 1992, pp. 405-430.

[20] R. Hickey-Vargas, Origin of the Indian Ocean-type isotopic signature in basalts from Philippine Sea plate spreading centers: An assessment of local versus largescale processes, J. Geophys. Res. 103 (B9) (1998) 20963 20979.

[21] R. Hickey-Vargas, Isotope characteristics of submarine lavas from the Philippine Sea: Implications for the origin of arc and basin magmas of the Philippine tectonic plate, Earth Planet. Sci. Lett. 107 (1991) 290-304.

[22] R.N. Taylor and R.W. Nesbitt, Arc volcanism in an extensional regime at the initiation of subduction: a geochemical study of Hahajima, Bonin Islands, Japan, in: J.L. Smellie (Ed.), Volcanism Associated with Extension at Consuming Plate Margins, Geological Society London Special Publication 81 (1995) 115-134.

[23] R.N. Taylor, R.W. Nesbitt, P. Vidal, R.S. Harmon, B. Auvray, I.W. Croudace, Mineralogy, chemistry, and genesis of the boninite series volcanics, Chichijima, Bonin Islands, Japan, J. Petrol. 35 (3) (1994) 577-617. 
[24] R. Hickey-Vargas, J.M. Hergt and P. Spadea, The Indian Ocean-type signature in western Pacific marginal basins: origin and significance, in: B. Taylor and J. Natland (Eds.), Active Margins and Marginal Basins of the Western Pacific, American Geophysical Union Geophysical Monograph 88 (1995) 175-197.

[25] L.E. Johnson, P. Fryer, The first evidence for MORB-like lavas from the outer Mariana forearc: geochemistry, petrography and tectonic implications, Earth Planet. Sci. Lett. 100 (1990) 304-316.

[26] L.E. Johnson, P. Fryer, B. Taylor, M. Silk, D.L. Jones, W.V. Sliter, T. Itaya, T. Ishii, New evidence for crustal accretion in the outer Mariana fore arc Cretaceous radiolarian cherts and mid-ocean ridge basalt-like lavas, Geology 19 (1991) 811-814.

[27] S.H. Bloomer, B. Taylor, C.J. MacLeod, R.J. Stern, P. Fryer, J.W. Hawkins and L. Johnson, Early arc volcanism and the ophiolite problem: A perspective from drilling in the Western Pacific, in: B. Taylor and J. Natland (Eds.), Active Margins and Marginal Basins of the Western Pacific, American Geophysical Union Geophysical Monograph 88 (1995) 1-30.

[28] N. Takahashi, K. Suyehiro, M. Shinohara, Implications from the seismic crustal structure of the northern Izu-Bonin arc, Isl. Arc 7 (1998) 383-394.

[29] A. Taira, H. Tokuyama and W. Soh, Accretion tectonics and evolution of Japan, in: Z. Ben-Avraham (Ed.), The Evolution of Pacific Ocean Margins, Oxford Univ. Press, New York, 1989, pp. 100-123.

[30] K. Suyehiro, N. Takahashi, Y. Ariie, Y. Yokoi, R. Hino, M. Shinohara, T. Kanazawa, N. Hirata, H. Tokuyama, A. Taira, Continental crust, crustal underplating, and low-Q upper mantle beneath an oceanic island arc, Science 272 (1996) 390-392.

[31] W.S. Holbrook, S. Lizarralde, S. McGeary, N. Bangs, J. Diebold, Structure and composition of the Aleutian island arc and implications for continental crustal growth, Geology 27 (1) (1999) 31-34.
[32] M.M. Fliedner, S.L. Klemperer, Structure of an island arc: Wide-angle seismic studies in the eastern Aleutian Islands, Alaska, J. Geophys. Res. 104 (B5) (1999) 10667-10694.

[33] M.A. Khan, R.J. Stern, R.F. Bribble, B.F. Windley, Geochemical and isotopic constraints on subduction polarity, magma sources, and paleogeography of the Kohistan intra-oceanic arc, northern Pakistan Himalaya, J. Geol. Soc. London 154 (1997) 935-946.

[34] Amongst Lower to Upper Crustal Components in an Island Arc: the Jurassic Bonanza arc, Vancouver Island, Canada, Can. J. Earth Sci. (in press).

[35] D. Karig, Structural history of the Mariana island arc, Geol. Soc. Am. Bull. 82 (1971) 323-344.

[36] D. Karig and B. Ranken, Marine geology of the forearc region, southern Mariana island arc, in: D.E. Hayes (Ed.), The Tectonic and Geologic Evolution of Southeast Asian Seas and Islands (Pt. II), American Geophysical Union Geophysical Monograph 27 (1983) 266-280.

[37] K. Hinz and M. Block, Summary of geophysical data from the Sulu and Celebes seas, in: C. Rangin, E.A. Silver and M.T. von Breymann et al. (Eds.), Proceedings of the Ocean Drilling Program, Initial Reports, 124, Ocean Drilling Program, College Station, TX, 1990, pp. 87-92.

[38] C. Rangin, E.A. Silver and K. Tamaki, Closure of western Pacific marginal basins: rupture of the oceanic crust and the emplacement of ophiolites, in: B. Taylor and J. Natland (Eds.), Active Margins and Marginal Basins of the Western Pacific, American Geophysical Union Geophysical Monograph 88 (1995) 405-417.

[39] S.R. Taylor and S.M. McLennan, The Continental Crust: its Composition and Evolution, Blackwell, Oxford, 1985.

[40] A.G. Hochstaedter, J.B. Gill, J.D. Morris, Volcanism in the Sumisu Rift, II. Subduction and non-subduction related components, Earth Planet. Sci. Lett. 100 (1990) 195 209. 